\title{
Manajemen Strategik Pondok Pesantren dalam Upaya Membentuk Santri yang Berkarakter
}

\author{
Hasanudin ${ }^{*}$, Dadang Kuswana ${ }^{1}$, Dewi Sadiah ${ }^{2}$ \\ 1Jurusan Pengembangan Masyarakat Islam, Fakultas Dakwah dan Komunikasi, UIN Sunan \\ Gunung Djati, Bandung \\ 2Jurusan Manajemen Dakwah, Fakultas Dakwah dan Komunikasi, UIN Sunan Gunung Djati, \\ Bandung \\ *Email : hasanudin085703825017@gmail.com
}

\begin{abstract}
ABSTRAK
Penelitian ini bertujuan untuk menemukan kejelasan tentang formulasi strategi, implementasi strategi, dan evaluasi serta pengendalian strategi pada Pondok Pesantren Al-Masthuriyah dalam upaya membentuk santri yang berkarakter. Metode yang digunakan pada penelitian ini adalah deskriptif dengan pendekatana kualitatif. Pengumpulan data dilakukan dengan teknik observasi, wawancara, dan dokumentasi sehingga data dapat terkumpul dan dianalisis dengan baik. Penelitian ini menemukan bahwa manajemen strategik Pondok Pesantren Al-Masthuriyah telah diterapkan sesuai dengan tahap-tahap manajemen strategik, yaitu formulasi strategi yang didasarkan pada hasil analisis SWOT, kemudian dituangkan dalam keputusan strategi-strategi yang menjadi nilai jual inti pondok pesantren. Implementasi strategi telah berjalan dengan baik, yaitu dengan melaksanakan program-program yang tersusun, serta penerapan tata tertib santri. Evaluasi dan pengendalian strategi dilakukan secara terus menerus oleh pimpinan, pengurus, dan karyawan dengan agenda dan jenis rapat yang berbeda. Akhirnya dari seluruh tahapan manajemen strategik yang telah ditetapkan dapat disimpulkan bahwa manajemen strategik pada Pondok Pesantren Al-Masturiyah telah dijalankan dengan baik dan menunjukan keberhasilan yang cukup signifikan dalam upaya membentuk santri yang bekarakter
\end{abstract}

Kata Kunci: Manajemen Strategik; Pondok Pesantren; Karakter.

\section{ABSTRACT}

This study aims to find clarity about strategy formulation, strategy implementation, and evaluation and strategy control at Al-Masthuriyah Islamic Boarding School in an effort to form santri with character. The method used in this research is descriptive method with a qualitative approach. Data collection is done by observation, interview, and documentation 
Hasanudin, D. Kuswana, D. Sadiah.

techniques so that the data can be collected and analyzed properly. This study found that the strategic management of Al-Masthuriyah Islamic Boarding School has been applied in accordance with the stages of strategic management, namely the formulation of strategies based on the results of the SWOT analysis, then poured into decisions on strategies that are the core selling points of Islamic boarding schools. The implementation of the strategy bas been going well, namely by implementing structured programs, as well as the application of the santri code of conduct. Strategy evaluation and control are carried out continuously by leaders, management and employees with different agendas and types of meetings. Finally, from all the stages of strategic management that have been determined, it can be concluded that the strategic management at Al-Masturiyah Islamic Boarding School has been carried out well and has shown significant success in the effort to form students with character.

Keywords : Strategic Management; Islamic Boarding School; Character

\section{PENDAHULUAN}

Pondok pesantren sebagai salah satu lembaga pendidikan pertama dan tertua di Indonesia, yang eksistenisnya tidak diraguakan lagi di tengah-tengah masyarakat, terutama masyarakat pulau Jawa, pondok pesantren dianggap sebagai produk asli budaya Indonesia yang Indigenous, merupakan salah satu sarana bagi umat Islam di Indonesia untuk mendalami syari'at Islam. Keragaman pondok pesantren yang senantiasa mewarnai khazahan budaya bangsa, khususnya ikut serta dalam mencerdaskan kehidupan bangsa melalui nilai-nilai Agama (Islam), telah melahirkan suatu lembaga pendidikan yang mandiri yang pada hakikatnya merupakan praktek pendidikan berbasis masyarakat (community based education).

Selain itu, Pondok Pesanten merupakan suatu lembaga yang memiliki struktur, sistem, mekanisme, metodologi pembelajaran, kurikulum dan aturanaturan khusus lainnya yang menjadi ciri khas lembaga ponodok pesantren dengan lembaga yang lain. Keberadaan pesantren yang kurang lengkap oleh perangkat di atas tidak mengurangi makna pesantren sebagai organisasi dakwah. Pondok pesantren sebagai lembaga pendidikan non formal yang tersebar di Indonesia, dimana pondok pesantren lahir di tengah-tengah masyarakat khususnya di tanah Jawa. Setiap pondok pesantren mempunyai ciri khasnya masing-masing baik itu dari budaya, metode pembelajaran dan yang lainnya, tergantung dari tipe leadership kiai nya.

Manajemen strategik (strategic management) menurut Wheelen dan Hunger (2004: 2) adalah serangkaian keputusan dan tindakan manajerial yang dihasilkan dari proses formulasi dan implementasi rencana dengan tujuan untuk mencapai keunggulan kompetitif. Bila definisi ini perlu dikaitkan dengan terminologi "manajemen", maka manajemen strategik dapat pula didefinisikan sebagai: proses perencanaan, pengarahan (directing), pengorganisasian dan pengendalian sebagai keputusan dan tinndakan strategis lembaga atau perusahaan dengan tujuan untuk mencapai keunggulan kompetitif (Solihin, 2012 : 64). 
Adapun dalam istilah bahasa Arab Istilah Manajemen diartikan sebagai an-nizam atau at-tanzim, yang merupakan suatu tempat untuk menyimpan segala sesuatu dan penempatan sagala sesuatu pada tempatnya (Munir, dan wahyu Ilahi, 2006: 9) selain itu, dijelaskan dalam perkataan Ali bin Abi Thalib, karomallau wajhah. bahwa "Al-haqqu bila nidrom yaghlibubu Al-baathil binnidzom" maknanya: "suatu kebenaran yang tidak terorganisir akan dikalahkan oleh kebatilan yang terorganisir". Oleh karena itu, menurut pandangan penulis di era modern sekarang hendaknya lembaga-lembaga yang ada di Indonesia khusunya lembaga dakwah yang mempunyai tujuan yang baik demi kemashlahatan ummat, maka harus dijalankan secara terorganisir demi mencapai tujuan lembaga dakwah itu sendiri.

Dalam proses mengaplikasikan manajemen strategik baik untuk sebuah perusahaan maupun untuk lembaga, Wheelen dan Hunger (2004 : 14) dalam (Solihin, 2012 : 78), mengembangkan model manajemen strategik menjadi empat tahapan proses, yaitu: (1) analisis/pengamatan lingkungan, (2) formulasi strategi. (3) implementasi strategi, (4) evaluasi dan pengendalian strategi.

Pondok Pesantren Al-Masthuriyah terletak sekitar $7 \mathrm{~km}$ arah barat Kota Sukabumi, pesantren Al-Masthuriyah yang lebih dikenal oleh masyrakat sekitar dengan julukan 'Pesantren Tipar' berdiri sejak tahun 1920 dikampung Tipar, Desa Cibolangkaler, Kecamatan Cisaat, Kabupaten Sukabumi. Pada awal berdirinya pada tahun $1330 \mathrm{H}$ Pesantren ini hanyalah sebuah madrasah yang diberi nama Madrasah Ahmadiyah yang didirikan oleh salah satu ulama Sukabumi Yaitu KH. Masthuro. (Dokumen Pondok Pesantren Al Masthuriyah). Pondok pesantren ini berada di bawah naungan yayasan yang didalamnya bukan hanya pesantren saja melainkan terdiri atas RA, MD, MI, SMP, MTS, SMA, MA, SMK, Pendidikan Diniyah Formal (PDF) dan STAI ,KBIH. hal ini dilakukan bertujuan agar para santri selain menguasai ilmu agama juga mahir dalam ilmuilmu umum.

Dalam eksistensinya Pondok Pesantren Al-Masthuriyah ini senantiasa berupaya mendidik para santrinya agar mempunyai karakter dan akhlak sesuai akhlak Rasulullah SAW, hal ini dilakukan selain mengaji kitab kuning sebagai panduan utama para santri juga melalui pembinaan kemandirian, kedisiplinan, tanggung jawab, belajar kerjasama dan yang lainnya, agar semua santri terbiasa dan mempunyai karakter yang baik dimasa sekarang maupun dimasa yang akan datang. Keberhasilan Pondok Pesantren Al-Masthuriyah dalam membina dan mendidik para santrinya sehingga melahirkan alumni-alumni berkulaitas dalam bidang ilmunya masing-masing. Dan juga banyak melahirkan alumni yang menjadi tokoh masyarakat (Kiai), pemimpin, di daerahnya masing-masing bukan hanya di daerah Sukabumi saja melainkan di luar Sukabumi juga banyak. Dari keberhasilan tersebut, tentu tidak akan berhasil secara instan, karena pada hakikatnya segala sesuatu butuh proses, maka salah satu proses yang dilakukukan 
Hasanudin, D. Kuswana, D. Sadiah.

oleh Pondok Pesantren Al-Masthuriyah dalam membina dan mendidik para santri-santrinya agar mempunyai karakter yang baik yaitu dengan menerapkan manajemen strategik yang meliputi; (1) analisis lingkungan, (2) formulasi strategi, (3) imlpementasi strategi, (4) evaluasi dan penendalian strategi, (Wheelen dan Hunger, 2004 : 11), sebagai ilmu atau alat untuk mengelola pondok pesantren agar tujuan yang dicita-citakan dapat tercapai secara efisien (Dokumen Pondok Pesantren Al-Masthuriyah).

Oleh sebab itu, dari yang sudah dipaparkan di atas peneliti merasa tertarik untuk melakukan penelitian secara komprehensif dan mendalam mengenai penerapan manajemen strategik di Pesantren Al-Masthuriyah dalam upaya membentuk santri yang berkarakter, dan dari hasil observasi awal peneliti juga menemukan adanya keunikan dari Pondok Pesantren Al-Masthuriyah yaitu selain sudah mashur di kalangan masyarakat Sukabumi juga sebagai salah satu lembaga pendidikan terbaik dan pavorit yang ada di Sukabumi yang senantiasa menggabungkan ilmu umum (modern) dan salaf (tradisional) sebagai salah satu metode yang digunakan dalam mendidik para santrinya.

Penelitian tentang pondok pesantren bukanlah ha yang baru, beberapa tulisan dan penelitian telah banyak dilakukan. Penelitian Hasan Munawar (2017), dengan judul Perencanaan Pondok Pesantren dalam Membentuk Kader Ulama. Fokus yang diteliti tentang proses perencanaan yang dilakukan oleh pengurus Pondok Pesantren Wahdatu Tauhid dalam membentuk kader ulama. Selanjutnya penelitian yang dilakukan oleh Ahmad Halil Naufal (2017),tentang Manajemen Strategik Pondok Pesantren dalam upaya Optimalisasi Bimbingan Tahfidz AlQur'an, penelitiannya berfokus pada proses manajemen strategik yang dilakukan oleh pengurus Pondok Pesantren Al-Falah Cicalengka dalam mengoptimalkan bimbingan tahfidz Al-Qur'an. Kemudian penelitian Asep Kurniawan (2016) tentang Manajemen Strategik Pondok Pesantren dalam Menyiapkan Kader Da'i yang berkualitas. Dengan fokus penelitian membahas tentang bagaimana menjalankan serangkaian proses manajemen strategi oleh pengurus Pondok Pesantren Terpadu Darussyifa Al-Fitroh dalam menyiapkan kader da'i yang berkulaitas.

Berdasarkan latar belakang di atas, penulis mengarahkan fokus penelitian setelah melakukan pengamatan awal pada Pondok Pesantren Al-Masthuriyah Sukabumi, dengan alasan yaitu sangat penting masalah ini untuk dibahas karena berkaitan dengan pengelolaan pondok pesantren. Maka dari itu, pertanyaanpertanyaan yang peneliti cantumkan adalah sebagai berikut; (1) Bagaimana proses formulasi strategi Pondok PesantrenAl-Masth uriyah dalam Upaya Membentuk Santri yang Berkarakter? (2) Bagaimana implementasi strategi Pondok Pesantren Al-Masthuriyah dalam upaya membentuk santri yang berkarakter? (3) Bagaimana evaluasi hasil serta pengendalian strategi Pondok Pesantren Al-Masthuriyah dalam upaya memebntuk santri yang berkarakter? 
Metode yang digunakan dalam penelitian ini adalah metode deskriptif dengan pendekatan kualitatif. Metode deskriptif adalah rumusan masalah yang mengarahkan penelitian untuk menjelajahi dan memotret keadaan sosial yang akan diteliti mendalam, menyeluruh dan luas tujuanya untuk menggambarkan dengan sistematis fakta atau bidang tertentu secara factual (Sadiah, 2015 : 4).

\section{LANDASAN TEORITIS}

Dalam penelitian ini, peneliti kemukakan teori tentang manajemen strategik., pondok pesantren, dan karakter. Pertama. Pengertian manajemen strategik. Manajemen strategik secara etimologi berasal dari dua kata yang berbeda "manajemen" dan "strategik" masing-masing mempunyai arti yang berbeda pula. Manajemen dalam bahasa Inggris dikenal dengan kata manage yang berarti mengurus, mengatur, mengelola, dan melaksanakan (John M. Echols \& Shadily, 2003: 372). Adapun dalam Kamus Umum Bahasa Indonesia (W.J.S. Poerdarminta, 2007: 742) manajemen diartikan sebagai cara mengelola suatu perusahaan yang besar, pengelolaan atau pengaturan dilaksanakan oleh seorang manajer (pengatur/pimpinan) berdasarkan urutan manajemen (Badrudin, 2013: 1). Dalam bahsa Arab, istilah manajemen diartikan sebagai an-nizam atau attanzim, merupakan tempat untk menyimpan segala sesuatu dan penempatan segala sesuatu pada tempatnya (Munir dan Wahyu Ilahi, 2006: 9).

Adapun secara terminologi menurut G.R Terry dalam Hasibuan, (2006: 2) mengemukakan manajemen adalah suatu proses yang khas yang terdiri dari tindakan-tindakan perencanaan, pengorganisasian, pengarahan, dan pengendalian yang dilakukan untuk menentukan serta mencapai sasaran-sasaran yang telah ditentukan melalui pemanfaatan sumber daya manusia dan sumber lainnya.

Dalam buku Malayu S.P. Hasibuan (2006: 102) strategi diartikan sebagai siasat yang merupakan salah satu jenis rencana, karena akan menetukan tindakan-tindakan pada masa yang akan datang untuk mencapai tujuan yanng diinginkan. Strategi ini pada hakikatnya adalah suatu interpretative planning yang dibuat dengan memperhitungkan rencana saingan. Penyusunan strategi (siasat) ini didasarkan atas pemanfaatan keunggulan-keunggulan kita daripada saingan. Strategi juga pada dasarnya adalah penentuan cara yang harus dilakukan agar memungkinkan memperoleh hasil yang optimal, efektif, dan dalam jangka waktu yang relatif singkat serta tepat menuju tercapainya tujuan yang telah ditetapkan.

Dari kedua kata "manajemen" dan "strategi" diatas, maka Manajemen Strategi secara terminologi adalah seni dan ilmu formulasi, implementasi dan evaluasi berbagai fungsi manajemen yang memungkinkan suatu organisasi mencapai tujuan-tujuannya (Kadmasasmita, 2005: 3).

Wheelen dan Hunger dalam Ismail Solihin (2012: 78), menggambarkan model manajemen strategik ke dalam empat tahapan proses, yaitu; (1) pemindaian lingkungan, adalah suatu kegiatan monitoring (pemantauan), 
Hasanudin, D. Kuswana, D. Sadiah.

pengevaluasian, dan penyebaran informasi yang berasal dari lingkungan internal maupun eksternal perusahaan kepada personel kunci di dalam sebuah perusahaan. Kegiatan ini terdiri atas pemindaian lingkungan terhadap lingkungan ekternal perusahaan yang dikelompokan oleh Wheelen dan Hunger sebagai societal environmet (dalam lingkungan perusahaan) dan task environment (luar lingkungan perusahaan). pemindaian ini ditunjukan untuk melakukan analisis (SWOT) terhadap keukatan dan kelemahan yang dimiliki oleh sumber daya perusahaan, proses internal perusahaan yang tergambar dari bagaimana sebuah perusahaan mampu menciptakan nilai bagi para pelanggan dan analisis terhadap budaya perusahaan. (2) Formulasi strategi, Pada tahap formulasi strategi perusahaan secara berkala mengkaji ulang misi dan tujuan perusahaan serta merumuskan kembali strategi yang sesuai dengan misi dan tujuan perusahaan tersebut. Misi dan tujuan perusahaan cenderung mengalami perubahan sesuai dengan strategi yang dipilih oleh perusahaan (Solihin, 2012: 82).

Sebagian fakar mengatakan bahwa formulasi strategi sebetulnya mencakup analisis lingkungan organisasi (analisis SWOT). Hal ini, sesuai dengan tahapan formulasi strategi itu sendiri sebagaimana dikutip oleh Irsyad (2008 : 45-46). (3) Implementasi strategi, tujuan dan strategi sebuah perusahaan yang telah disusun dapat diimplementasikan dengan baik apabila tujuan dan strategi tersebut dituangkan ke dalam rangkaian kegiatan dalam bentuk program yang terjadwal secara jelas serta memperoleh alokasi sumber daya yang memadai dan telah dituangkan secara rinci dalam bentuk anggaran yang mendukung terhadap berjalannya program. Adapun program-program yang disusun oleh perusahaan selanjutnya harus didukung dengan prosedur yang menjelaskna secara terprinci dan jelas bagaimana suatu kegiatan atau pekerjaan harus dilakukan. Prosedur secara tidak langsung akan menjelaskan berbagai aktivitas yang harus dilakukan untuk menuntaskan suatu program. Selain itu, perusahaan juga dituntut untuk mengembangkan struktur organisasi yang akan memudahkan implementasi strategi yang telah dipilih oleh perusahaan maupun organisasi (Ismail Solihin, 2012: 82). (4) Evaluasi dan pengendalian strategi, tahap ini merupakan tahap terakhir dari manajemen strategik yang dikemukakan oleh Wheelen dan Hunger, pada tahap evaluasi perusahaan akan membandingkan kinerja aktual yang teah dicapai perusahaan dengan melihat dari standar kinerja. Hasil dari evaluasi ini, akan dijadikan patokan bagi perusahaan dalam melakukan pengedalian yakni apakah ada ketidaksesuaian antara kinerja aktual dengan kinerja standar? Jika ada maka perlu dilakukan tindakan koreksi.Selain itu, hasil dari evaluasi dan pengendalian juga akan menjadi timbal balik (feedback) bagi perusahaan supaya perusahaan melakukan perbaikan dalam setiap langkah proses manajemen strategik sejak pemindaian lingkungan sampai tahap evaluasi dan penngendalian (Solihin, 2012: 83).

Kedua, pondok pesantren. Berasal dari dua kata yang berbeda. Kata 
pondok berasal dari pengertian asrama-asrama para santri yang kemudian disebut pondok atau suatu tempat tinggal yang terbuat dari bambu, atau kata pondok juga bisa berasal dari bahsa arab fundug yang berarti hotel atau asrama (Dhofier, 1982: 17). Adapun istilah pesantren pada awalnya diambil dari kanta santri, yang diawali kata pe dan diakhiri kata an yang berarti tempat tinggal para santri. Profesor Johns dalam Zamaksyari Dhofier (1982: 18) berpendapat bahwa istilah santri berasal dari bahsa tamil yang berarti guru mengaji.

Dari kedua istilah pondok dan pesantren tersebut kemudian disatukan menjadi satu definisi oleh M. Arifin dalam Mujamil Qomar (tth: 2) bahwa pondok pesantren merupakan suatu lembaga pendidikan agama Islam yang tumbuh serta diakui oleh masyarakat sekitar, dengan sistem asrama (komplek) dimana para santri menerima pendidikan agama Islam melalui sistem pengajian atau madrasah yang sepenuhya berada dibawah kedaulatan dari gaya kepemimpinan seorang atau beberapa orang kiai dengan ciri-ciri khas yang bersifat karismatik serta independen dalam segala hal. Selain itu, lembaga research Islam (pesantren luhur) mendefinisikan pesantren sebagai suatu tempat yang tersedia untuk para santri dalam menerima pelajaran-pelajaran agama Islam sekaligus tempat berkumpul dan tempat tinggalnya (Qomar, th: 2).

Ketiga,karakter secara etimologi karakter diambil dari bahasa Latin "kharakter", "kharassein", "kharax", adapun dalam bahsa Inggris berasal dari kata "character" dan dalam bahasa Indonesia "karakter", yang mempunyai makna membuat tajam, membuat dalam. Dalam kamus Poerwadarminta, karakter diartikan sebagai tabi'at, watak, sifat-sifat kejiwaan, akhlak atau budi pekerti yang menjadi ciri khas seseorang (Majid \& Dian Andayani, 2012: 11).

Adapun karakter secara terminologi menurut Hornby \& Parnewel dalam Abdul Majid \& Dian Andayani (2012: 11) bahwa karakter adalah kualitas mental atau moral, kekuatan moral, nama atau reputasi. Hermawan Kertajaya (2010: 3) karakter merupakan ciri khas yang dimiliki suatu benda atau individu, ciri khas tersebut asli dan kemudian mengakar pada kepribadian benda atau individu tersebut dan juga merupakan mesin pendorong bagaimana seseorang bertindak, berskap, berujar, dan merspon sesuatu.

Secara umum karakter merupakan prilaku manusia yang berhubungan dengan Tuhan, diri sendiri, sesama manusia, lingkungan, dan kebangsaan, yang terwujud dalam pikiran, sikap, perasaan, perkataan, dan perbuatan berdasarkan norma-norma agama, hukum, tata krama, budaya, dan adat istiadat (Octavia, dkk, 2014: 11).

\section{HASIL DAN PEMBAHASAN}

Pondok pesantren Al-Masthuriyah merupakan salah satu pondok pesantren yang ada di wilayah Kabupaten Sukabumi, tepatnya di Kp. Tipar RT 049 RW 010 Desa Cibolangkaler Kecamatan Cisaat Kabupaten Sukabumi Provinsi Jawa 
Hasanudin, D. Kuswana, D. Sadiah.

Barat. Kabupaten Sukabumi merupakan salah satu basis kota yang berkomitmen membangun masyarakat yang madani dan religius. Pondok Pesantren AlMasthuriyah didirikan oleh KH. Masthuro, pada awal berdirinya Pondok Pesantren ini, ketika KH. Masthuro telah selesai menyelesaikan studinya kurang lebih dalam kurun waktu 13 tahun lamanya diberbagai pesantren/kiai dan sekolah/madrasah, pada tahun 1920 beliau kembali ke kampung halamanya pada saat itu kondisi kampung halamannya belum mengalami perubahan dari 13 tahun sebelumnya,walaupun mayoritas penduduknya memeluk agama Islam, namun dalam kehidupan sehari-harinya belum menggambarkan kehidupan yang Islami, bahkan terkesan sebaliknya, kemaksiatan merajalela dan dilakukan secara trang-trangan (vulgar), seperti judi, sambung ayam, ronggeng yang menjurus pada prostitusi dan madat. Selain itu pada saat itu, berkembang suatu kepercayaan atau aliran yang disebut Hakok. Dari kondisi masyarakat tersebutlah yang mendorong KH. Masthuro untuk mendirikan lembaga pendidikan Islam sebagai tempat pembinaan manusia yang berguna bag dirinya dan orang lain, dapat menuntut dirinya dan orang lain untuk meninggalakan hal-hal yang dilarang oleh Allah SW'T dan menjalankan segala perintahnya.

Pada tanggal 9 Rabi'ul Akhir 1338 H, bertepatan dengan tanggal 1 Januari 1920 M, mulailah KH. Masthuro mendirikan madrasah di kampung Tipar yyang diberi nama sekolah Ahmadiyah, sebagai dari cabang Ahmadiyah Sukabumi. Pada setiap harinya, beberapa murid tidak pulang ke rumahnya, tetapi mereka tinggal di masjid untuk menghafalkan pelajaran yang telah diberikan pada saat sekolah. Melihat situasi ini, KH. Masthuro memanfaatkannya dengan menambah pelajaran di masjid. Oleh karena itu, sekitar dua bulan setelah pendirian sekolah/madrasah, didirikanlah pondok pesantren.

Pada tahun 1935, KH. Masthuro menunaikan ibdah haji atas jasa baik dari seorang dermawan di kampung Cikukulu desa Cisadane. Pada tahun 1941 madrasah ini memisahkan diri dari induknya (Madrasah Ahmadiyah sukabumi) dan berdiri sendiri dan diberi nama Sekolah Agama Sirojul Atfal. Hal ini dilakukan dengan berbagai pertimbangan, KH. Masthuro memusatkan perhatiannya pada pendidikan dan dibantu oleh alumni sekolah Ahmadiyah Sukabumi, yaitu M. Mukhtar dan M. Syarkowi.

Pada tahun 1950, KH. Masthuro atas saran dan hasil musyawarah putraputri serta para penerusnya, maka beliau mendirikan sekolah baru, yaitu Sekolah Agama Sirojul Banat yang diperuntukan khusus bagi perempuan. Pada perkembangan selanjutnya, setelah salah seorang putra KH. Masthuro yaitu KH. E. Fakhruddin Masthuro menyelesaikan pendidikan di Pondok Pesantren Ciharashas Cianjur, ia diberi tugas oleh KH. Masthuro untuk memulai berkiprah di lembaga pendidikan, atas asaran dan usulan dari keluarga dan berbagai pihak serta tuntutan kebutuhan masyarakat, maka pada tahun 1966 didirikanlah Madrasah Tsanawiyyah Sirojul Athfal/Banat, dengan bobot pendidikan 75\% 
meterinya tentang Agama Islam dan 25\% tentang Ilmu umum. Bagi Sirojul Athfal/Banat masuknya materi pendidikan umum bukanlah suatu hal yang asing, karena sejak awal pendiriannya telah diberikan pendidikan kemasyarakatan dan pendidikan keterampilan, dalam bentuk yang praktis. Pendidikan kemasyarakatan diajarkan dengan pendekatan keagamaan atau penerapan ajaran Islam dalam kehidupan sehari-hari, sementara pendidikan keterampilan antara lain dalam bidang pertanian terutama peternak ikan.

Pada tahun 1967/1968, didirikan Madrasah Aliyah Sirojul Athfal/Banat, sebagai kelanjutan dari Madrasah Tsanawiyah. Setelah KH. Masthuro wafat pada tanggal 27 Rajab tahun 1968, estapeta perjuangannya diteruskan oleh putra dan putri, mantu serta para alumni. Sebagai tafa'ul terhadap pendiri, berdasarkan hasil musyawarah alumni tahun 1974, madrasah/sekolah Sirojul Athfal/Banat diubah menjadi Al-Masthuriyah.

Al-Masthuriyah mengalami perkembangan yang pesat dan diposisikan sebagai salah satu lembaga pendidikan Islam bertaraf Nasional dan peserta didik dari berbagai daerah di Indosesia bahkan ada yang berasal dari negara tetangga. Saat ini, Al-Masthuriyah (Yayasan Al-Masthuriyah) dalam bidang pendidikan selain membina pondok pesantren, juga membina RA, Mi, MD/DTA, MTS, SMP, MA, SMA, SMK, dan STAI. Dalam bahsa Arab, istilah manajemen diartikan sebagai an-nizam atau at-tanzim, merupakan tempat untk menyimpan segala sesuatu dan penempatan segala sesuatu pada tempatnya, (Munir dan Wahyu, 2006: 9).

Dasar pendidikan di Pondok Pesantren Al-Masthuriyah adalah ma'rifat kepada Allah SWT. Visi Pondok Pesantren Al-Masthuriyah adalah membangun sumber daya manusia yang mempunyai integritas keilmuan dan berakhlakul karimah. Misi Pondok Pesantren Al-Masthuriya yaitu Mempersiapkan peserta didik dengan meamacu aspek intelektual, kepribadian, dan jasmaniyahnya, sehingga mampu menjunjung tinggi nilai-nilai keilmuan dengan akhlakul karimah. Secara umum karakter merupakan prilaku manusia yang berhubungan dengan Tuhan, diri sendiri, sesama manusia, lingkungan, dan kebangsaan, yang terwujud dalam pikiran, sikap, perasaan, perkataan, dan perbuatan berdasarkan norma-norma agama, hukum, tata krama, budaya, dan adat istiadat (Octavia, 2014 : 11).

Tujuan pendidikan Pondok Pesantren Al-Masthuriyah yaitu mempersiapkan anak didik dari segi afektif, kognitif, dan psikomotoriknya, sehingga bermanfaat bagi dirinya dan bagi lingkungannya.

\section{اعداد الطفل بدنيا و عقليا وروحيا ليكون نافعا لنفسه ولغير ها}

Membentuk santri dari segi jasmani, pikiran, dan rubaninya agar bermanfa'at bagi dirinya dan orang lain.

Formulasi Strategi Pondok Pesantren Al-Masthuriyah dalam Upaya membentuk Santri yang Berkarakter. Proses perumusan strategi yang dilakukan 
Hasanudin, D. Kuswana, D. Sadiah.

Pondok Pesantren Al-Masthuriyah sesuai dengan teori formulasi strategi, yaitu dimulai dari analisis internal pondok pesantren yang terdiri dari kegiaitan menganalisa keukatan dan kelemahan yang dimiliki oleh Pondok Pesantren AlMasthuriyah, selanjutnya menganalisis peluang dan ancaman berupa hal-hal yang mungkin terjadi dari eksternal pondok pesantren, setelah dilakukan analisis SWOT maka langkah selanjutnya yaitu menentukan strategi-strategi dalam upaya membentuk santri yang berkarakter yaitu berupa strategi utama, strategi umum, dan menentukan program utama pondok pesantren: Pertama, analisis internal pondok pesantren Al-Masthuriyah terdiri dari dua hal, yaitu; (a) kekuatan, diantara kekuatan yang dimiliki oleh internla pondok pesantren Al-Masthuriyah dalam upaya memebntuk karakter santri yaitu; Pondok Pesantren AlMasthuriyah sudah memiliki bangunan sendiri, sehingga proses mengaji santri bisa kondusif, Pondok Pesantren Al-Masthuriyah sudah memiliki pasilitas, sarana, dan prasarana yang lengkap,Pimpinan (ajengan), pengurus, asatidz/asatidzah, pembimbing Pondok Pesantren Al-Masthuriyah selalu memantau dan membimbing seluruh kegiatan santri, Para santri mempunyai kesadaran untuk senantiasa mengikuti seluruh program dan pengajian yang ada di Pondok Pesantren Al-Masthuriyah, Santri senantiasa menjunjung tinggi nilainilai akhlakul karimah baik terhadap guru (yang lebih ushoktama), terhapap teman dan masyrakat lainnya, (b) kelemahan, diantara kelemahan yang dimiliki internal Pondok Pesantren Al-Masthuriyah dalam membentuk santri yang berkarakter adalah; Pengurus maupun pembimbing tidak bisa mengawasi santri 24 jam penuh karena mempunyai keterbatasan waktu dan kesibukan yang lain, Pengurus belum bisa $100 \%$ memberikan contoh keteladanan yang baik (uswab) terhadap santri, Ada sebagian santri yang tidak mau sepenuhnya mengikuti pembelajaran dalam konteks pondok pesantren, hal ini dipengaruhi oleh budaya sekolah, sehingga budaya sekolah lebih kuat pengaruhnya dibandingkan dengan pondok pesantren, Masih ada sebagian santri yang berani melanggar aturan (tata tertib) pondok pesantren dan berani meninggalkan program pondok pesantren, Hilangnya figur sentral di pondok pesantren sehingga mempengaruhi proses pembentukan karakter santri.

Kedua, analisis eksternal Pondok Pesantren Al-Masthuriyah terdiri dari dua hal, yaitu; (a) peluang, peluang ekternal Pondok Pesantren Al-Masthuriyah dalam upaya memmbentuk santri yang berkarakter diantaranya; Pondok pesantren Al-Masthuriyah berada wilayah kota santri, maksudnya bahwa di daerah Cisaat tersebut masih banyak pondok pesantren yang lain, karena awal penyebaran ilmu Syariat Islam di Kabupaten Sukabumi berasal dari Cisaat salah satunya yaitu Pondok Pesantren Al-Masthuriyah, Melakukan kerjasama dengan alumni untuk sesantiasa mensosialisasikan dan memberi motivasi terhadap santri. (b) ancaman, diantara ancaman ekternal Pondok Pesantren Al-Masthuriyah dalam upaya membentuk santri yang berkarakter adalah; Pondok Pesantren Al-Masthuriyah 
berda di desa transisi dan dekat dengan perkotaan sehingga tidak menutup kemungkinan akan mempengaruhi gaya hidup dan karakter santri, Pengaruh zaman yang sudah berubah sehingga sedikit-demi sedikit merubah pola pikir santri, Perkembangan teknologi informasi dan kominikasi khususnya internet, media sosial, di samping banyak manfaatnya justru lebih banyak madharat-nya bagi santri sebab akan masuknya pemikiran-pemikiran dan budaya barat yang berasal dari Barat.

Ketiga, strategi utama, ada beberapa strategi utama yang diterapkan oleh Pondok Pesantren Al-Masthuriyah dalam membentuk santri yang berkarakter, yaitu; (a) Menyelenggarakan pembinaan khusus untuk para santri yang dilakukan dua kali dalam satu minggu malam Rabu (untuk santri putra) dan malam Sabtu (untuk santri putri), (b) Menyelenggarakan pengajian khusus kitab yang mengkaji tentang karakter diantaranya; kitab Akblakul Banin, Akblakul Banat, Ta'limul Muta'allim, Sulam At-Taufik, Uqud Al-Lujain, Minhajul 'Aabidiin dan Burdah, (c) Berupaya mendidik para santri dari pembiasaan keseharian yaitu hal-hal terkecil dimulai dari pelaksanaan shalat berjamaah.

Keempat, strategi umum, ada beberapa strategi umum yang diterapkan Pondok Pesantren Al-Masthuiyah dalam upaya membentuk santri yang berkarakter, yaitu; (a) Menyelanggarakan program tahunan melalui acara halal bi halal sekaligus penutupan masa ta'aruf santri dengan mengahdirkan alumnialumni Pondok Pesantren Al-Masthuriyah yang sudah sukses untuk memberikan motivasi kepada santri baru maupun santri yang sudah lama, (b) Merancang dan memberlakukan tata tertib bagi santri, (c) Memberikan berbagai jenis sanksi terhadap santri yang malanggar tata tertib yang telah ditetapkan.

Kelima, program utama, dalam upaya membentuk santri yang berkarakter Pondok Pesantren Al-Masthuriyah membuat berbagai macam program utama agar santri terbiasa melakukan dan mematuhi pertauran setiap hari, programprogram tersebut adalah; (a)menggalakan shalat berjamaah, (b) Membiasakan shalat sunnat rawatib, (c) Menggalakan wirid, ratib, dan ayat khamsu (ayat lima), (d) Menghidupkan shalat tahajjud, dhuha, dan witir, (e) Pembiasaan puasa sunnat khususnya puasa senin kamis, (f) Menstabilkan pengajian, (g) Merumuskan target pengajian sesuai dengan tingkatannya, (h) Menggalakan kebersihan, dengan patrol, piket dan opsih, (i) Merumuskan kembali tata tertib santri, (j) Menyiapkan prangkat pendukung pelaksanaan tata tertib santri, (k) Sosialisasi tata tertib santri, (l) Merumuskan dan melaksanakan pananganan pelanggaran tata tertib, m)Melaksanakan pembinaan-pembinaan.

Selain itu, masalah datang dari sumber daya manusia yaitu santri dan juga asatidz, semua santri dalam segi menerima ilmu tidak sama, ada yang mampu menerima secara cepat dan ada juga yang lambat, serta adanya kendala santri yang tidak bisa mengikuti aturan pesantren sering melanggar aturan yang telah ditetapkan oleh pesantren. Adapun permasalahan yang pernah 
Hasanudin, D. Kuswana, D. Sadiah.

dialami yaitu pada kesejahteraan asatidz, karena asatidz merupakan manusia yang butuh akan materi jadi untuk memberikan kesejahteraannya harus ada fee yang di rasa layak untuk diberikan, kekurangan materi dari pihak pesantren berdampak pada kesejahteraan asatidz dengan kesejahteraannya tidak terpenuhi maka akan berdampak pada kegiatan mengajar, hal ini juga mempengaruhi terhadap target dalam mengajar. Adapun dalam menganalisis lingkungan internal pasti akan didapat kekuatan yang dimiliki pesantren serta kelemahannya (Kulsum, 2018 : 91).

\section{Implementasi Strategi Pondok Pesantren Al-Masthuriyah dalam Upaya Membentuk Santri yang Berkarakter}

Formulasi strategi ditujukan untuk menghasilkan berbagai strategi utama dan umum di tingkat korporasi (corporate strategy formulation) dengan arahan nilai utama dan orientasi strategis organsasi serta turunan berikautnya strategi fungsional (functional strategy formulation). Pemahaman menyeluruh atas ruang lingkup dan ragam strategi organisasi memberikan simpulan bahwa prisnsip pembuatan strategi sebenarnya adalah salah satu upaya untuk mempertahankan diri dalam lingkungan bisnis yang dinamis. Termasuk di dalamnya adalah upaya-upaya untuk meraih keuntungan materi dan imateri serta persaingan yang ada (Irsyad, 2008: 40).

Pondok pesantrenb erasal dari dua kata yang berbeda. Kata pondok berasal dari pengertian asrama-asrama para santri yang kemudian disebut pondok atau suatu tempat tinggal yang terbuat dari bambu, atau kata pondok juga bisa berasal dari bahsa arab fundug yang berarti hotel atau asrama (Dhofier, 1982: 17).

Setelah terbentuk struktur organisasi dan berjalan sesuai tugasnya masingmasing, langkah selanjutnya yaitu mengimplementasikan strategi-strategi yang telah dirancang oleh pengurus Pondok Pesantren Al-Masthuriyah. Adapun berbagai strategi yang diimplementasikan oleh pengurus Pondok Pesabtren AlMasthuriiyah dalam upaya mementuk santri yang berkarakter yaitu; (1) Melalui pendidikan keseharian dan itrakulikuler (pengajian), Strategi ini merupakan strategi inti dari proses pembentukan karakter santri Pondok Pesantren Al-Masthuriyah, dimana santri dituntut unruk mengikuti seluruh proses belajar yang telah ditentukan oleh pondok pesantren, hal ini bertujuan agar santri mempunyai wawasan keilmuan tentang syari'at Islam secara menyeluruh. Dan dalam proses pendidikan keseharian, santri juga dituntut untuk senantiasa disiplin dari segala hal dimulai dari hal-hal terkecil seperti shalat berjama'ah tepat waktu. (2) Melalui materi pengajian, Mengaji dan mengkaji materi (kitab kuning) yang membahas tetang karakter atau akhlak, diantaranya ; Akblakul Banin, Akblakul Banat, Ta'limul Muta'allim, Sullam At-Taufik, Uqud Al-Lujain, Minhajul 'Abdidin, dan Burdah.

Hal ini juga menjadi modal utama dalam proses pembentukan karakter 
santri, sebab dalam kitab-kitab tersebut dibahas segala aspek tentang nilai-nilai akhlak yang sesuai ajaran Islam. (3) Melalui pembinaan khusus, dalam proses pembentukan karakter santri, Pondok Pesantren Al-Masthuriyah membuat program pembinaan khusus mingguan untuk santri yang dilaksanakan setiap malam rabu khusus untuk santri putra dan malam sabtu untuk santri putri, hal ini dilakukan untuk mengevaluasi kegiatan selama satu minggu tersebut. Kegiatan dalam pembinaan ini yaitu memeriksa dan mencek ulang siapa saja santri yang tidak mengikuti pengajian dan program pondok melalui absesinsi pengajian. Jika ada santri yang tidak hadir dalam pengajian maka oleh pembimbing akan dipanggil lalu diberikan peringatan, arahan dan, bahkan sanksi yang telah berlaku. (4) Melalui kegiatan tahunan, kegiatan tahunan ini berupa acara hala bi hala sekaligus penutupan masa orientasi santri baru, pada kegiatan ini diisi dengan seminar dan memberikan motivasi terhadap santri baru maupun santri lama. Yang bertugas sebagai pengisi acara adalah alumni Pondok Pesantren AlMasthuriyah yang sudah sukses. Biasanya motivator tersebut menceritakan pengalamannya waktu mondok di Pondok Pesantren Al-Masthuriiyah dan diselipkan pembahasan tentang proses pembentukan karakter di Pondok Pesantren Al-Masthuriyah. (5) melalui penerapan tata tertib santri, dengan diberlakukannya tata tertib maka para santri diwajibkaan untuk selalu mematuhi tata tertib pondok pesantren.

Pada setiap proses tentunya pasti ada faktor pendukung dan penghambat terhadap berjalannya proses tersebut, begitupun dalam proses mengiplementasikan strategi-strategi terdapat beberapa faktor pendukung dan penghambat berjalannya strategi yang telah dirancang oleh pengurus Pondok Pesantren Al-masthuriyah dalam upaya membentuk santri yang berkarakter, diantara faktor pendukung adalah; (1) Sumber Daya Manusia (SDM), Pondok Pesantren Al-Masthuriyah mempunyai banyak tenaga kerja yang profesional dibidang ilmunya masing-masing dan hampir semua staf pengajar merupakan alumni dari Pondok Pesantren Al-Masthuriyah sehinggi rasa memiliki dan tanggung jawabnya elbih besar. (2) fasilitas, sarana dan prasarana.Fasilitas, sarana dan prasarana di Pondok Pesantren Al-Masthuriyah telah memadai sehingga proses belajar mengajar bisa berlangsung secara efektif dan efisien. (3) lembagalembaga. (4) uang/money, dana termasuk salah satu faktor utama sebagai penunjang untuk meningkatkan kualitas pesantren sebagai kebutuhan pokok jalannya suatu program yang telah direncanakan, sehingga mampu mempertahankan kulitas pesantren. Pondok pesantren Al-Masthuriyah memiliki sirkulasi keuangan yang cukup baik, baik dari spp santri maupun dari donatur. (5) Masyarakat, Masyarakat di sekitar Pondok Pesantren Al-Masthuriyah sangat mendukung jalannya program-program pondok pesantren, sehingga memudahkan pondok pesantren dalam menyelenggrakan kegiatan. Adapun faktor penghambat implementasi strategi dalam upaya membentuk santri yang 
Hasanudin, D. Kuswana, D. Sadiah.

berkarakter yaitu; (1) Pengurus Pondok Pesantren Al-Masthuriyah belum bisa $100 \%$ memberikan suri tauladan yang baik terhadap santri. (2) Keterbatasan waktu pengurus dalam mengawasi dan membimbing santri. (3) Ada sebagian santri yang masih berani melanggar tata tertib. (4) Ada sebagian orang tua santri yang masih pro terhadap anaknya ketimbang aturan pondok pesantren, sehingga ketika anaknya dikenakan santri maka dia melapor polisi atau diviralkan dimedia social.

Beriring perkembangan zaman dan teknologi di era modern ini keberadaan pondok pesantren tetap masih terus eksis dan berkembang. Terutama dari aspek manajemen pembangunannya. Menurut pengamat perkembangan pondok pesantren di Indonesia. Zamahsyari Dhofier (1984: 17) menyebutkan bahwa sejak masa awal perkembangan sampai sekarang ini, bentuk manajemen kemandirian pondok pesantren pada awalnya lahir dari kegigihan Kyai dan partisipasi masyarakat yang tinggi. Namun pada masa sekarang ini, dari kedua bentuk manajemen yang terus dikembangkan oleh para pengelola pondok pesantren di tanah air adalah manajemen kemandirian. Hal ini, terbukti dari beberapa pondok pesantren yang terkenal di Indonesia, seperti Pondok Pesantren Gontor dan Pondok Pasantren Daarut Tauhid. Kedua pondok pesantren ini terkenal dengan manajemen entrepreneur yang dijadikan sebagai program unggulan dalam meningkatkan kualitas dan kuantitas (Bob, 2017: 134).

\section{Evaluasi dan Pengendalian strategi Pondok Pesantren Al-Masthuriyah dalam upaya mementuk santri yang berkarakter}

Pengevaluasian merupakan suatu kegiatan atau usaha agar pekerjaan-pekerjaan terlaksana sesuai dengan rencana yang ditetapkan ayau hasil yang dikehendaki. Penyelenggaraan program majlis ta'lim akan dapat berjalan dengan baik dan lancar, bilamana kegiatan-kegiatan yang telah diserahkan kepada para pengurus dan jamaah itu sesuai dengan bidangnya masing-masing untuk dapat mengetahui apakah kegiatan-kegiatan sudah dilaksanakan, sejauhmana pelaksanaannya, maka pimpinan pesantren perlu senantiasa melaksanakan pengevaluasian sebab dengan pengevaluasian itu dapat diketahui keganjilan- keganjilan yang dilakukan serta dapat mengambil tindakan-tindakan pencegahan terhadap keganjilan tersebut. Selain itu dapat mengadakan usaha-usaha peningkatan dan penyempurnaan (Gozali, 2017: 51).

Evaluasi dan pengendalian strategi, tahap ini merupakan tahap terakhir dari manajemen strategik yang dikemukakan oleh Wheelen dan Hunger, pada tahap evaluasi perusahaan akan membandingkan kinerja aktual yang teah dicapai perusahaan dengan melihat dari standar kinerja. Hasil dari evaluasi ini, akan dijadikan patokan bagi perusahaan dalam melakukan pengedalian yakni apakah ada ketidaksesuaian antara kinerja aktual dengan kinerja standar? Jika ada maka perlu dilakukan tindakan koreksi.Selain itu, hasil dari evaluasi dan pengendalian 
juga akan menjadi timbal balik (feedback) bagi perusahaan supaya perusahaan melakukan perbaikan dalam setiap langkah proses manajemen strategik sejak pemindaian lingkungan sampai tahap evaluasi dan penngendalian (Solihin, 2012: 83).

Evaluasi dan penendalian strategi sebagai ilmu atau alat untuk mengelola pondok pesantren agar tujuan yang dicita-citakan dapat tercapai secara efisien (Wheelen dan Hunger, 2004 : 11).

Evaluasi dan pengendalian strategi di Pondok Pesantren Al-Masthuriyah sudah sangat efektif. Pada praktiknya, upaya dasar pengendalian strategi ini didasarkan pada pengamatan strategi (presmise control) yang terus menerus dilakukan oleh pimpinan dan seluruh pengurus pondok pesantren. Namun, sistem kedali yang ada di Pondok Pesantren Al-Masthuriyah ada di wewenang pimpinan pondok pesantren.

Evaluasi strategi dalam upaya membentuk santri yang berkarakter menurut sekretaris Pondok Pesantren Al-Masthuriyah (wawancara 27 Juli 2019) bahwa: Evaluasi strategi yang diupayakan oleh Pondok Pesantren AlMasthuriyah dilakukan dengan sangat jelas dan intensif, yaitu dengan beberapa kegiatan khusus evaluasi dalam hal rapat pimpinan, rapat pleno/rapat keraja (raker), rapat umum (rapat perguruan), rapat divisi, dan rapat istimewa yang merupakan agenda evaluasi. (1) Rapat Pimpinan, Rapat top management, rapat ini mencakup pimpinan pondok pesantren, wakabag, sekretaris umum dan bendahara umum untuk membahas kebijakan-kebijakan Pondok Pesantren AlMasthuriyah. (2) Rapat pleno/ rapat kerja,adalah kegiatan yang membahas tentang rumusan strategi dan membuat kebijakan untuk satu tahun kedepan. Rapat ini dihadiri oleh pimpinan pondok pesantren, pimpinan unit pendidikan, pimpinan lembaga (lembaga pengembangan bakat). Rapat ini dilaksanakan setiap satu tahun sekali, yaitu menjelang tahun ajarana baru. (3) Rapat divisi, yaitu rapat per divisi atau unit pendidikan rapat ini melibatkkan kepada divisi dan anggotanya untuk membahas perumusan dan pelaksanaan kebijakan Pondok Pesantren Al-Masthuriyah. 4) Rapat umum (rapat perguruan), yaitu rapat yang melibatkan semua pimpinan, guru, pengurus, dan pengawai pondok pesantren untuk mensosialisasikan kebijakan-kebijakan pimpinan pondok pesantre. Rapat ini dilaksanakan satu semester dua kali yaitu awal semester dan akhir semester. (5) Rapat istimewa, yaitu rapat yang bersipat insidental. Rapat ini dilaksanakan untuk membahas hal yang sangat penting dan mendesak. Rapat dipimpin langsung oleh pimpinan pondok pesantren. 


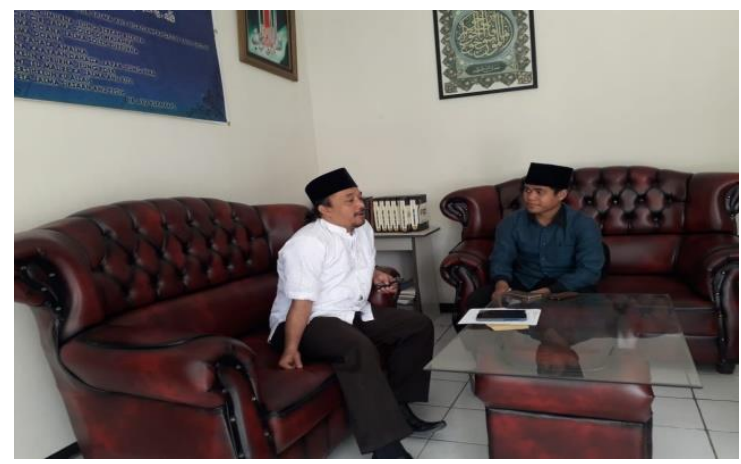

Gambar 1. Wawancara bersama sekretasi Pondok Pesantren AlMasthuriyah

\section{PENUTUP}

Berdasarkan uraian teori manajemen strategik dan hasil penelitian penulis di Pondok Pesantren Al-Masthuriyah Sukabumi, penulis menemukan adanya kegiatan manajemen strategik yang diawali dengan analisis lingkungan Pondok Pesantren Al-Masthuriyah yang dilakukan oleh tim perumus strategi secara intensif dan mendalam, dalam rangka membentuk santri yang berkarakter, dengan suatu kesimpulan sebagai berikut: (1) Formulasi strategi Pondok Pesantren Al-Masthuriyah dalam upaya membentuk santri yang berkarakter didasarkan pada hasil analisis SWOT, kemudian dituangkan dalam keputusan strategi-strategi yang menjadi nilai jual inti pondok pesantren. Keputusan yang diambil oleh tim perumus adalah mendukung kebijakan pertumbuhan yang agresif (growth oriented strategy), dengan memaksimalkan kekuatan internal dan mengambil peluang eksternal Pondok Pesantren, kemudian dituangkan dalam strategi utama berupa pertumbuhan terkonsentrasi (concentrated growth), pengembangan pusat (market development) dan pengembangan produk (product development). Hal ini dasar utama yaitu perubahan visi sebagai acuan untuk jangka panjang 5 (lima) tahun kedepan. (2) Implementasi strategi yang diterapkan oleh Pondok Pesantren Al-Masthuriyah dalam upaya membentuk santri yang berkarakter telah berjalan dengan baik, hal ini diwujudalakn demgan dilaksanakannya program-program yang tersusun, serta aturan-aturan/tata tertib yang dilaksankan dengan baik. (3) Evaluasi dan pengendalian strategi di Pondok Pesantren Al-Masthuriyah dalam upaya membentuk santri yang berkarakter sangat efektif, yang didasarkan pada pengamatan strategi dan pengendalian strategi secara terus menerus oleh direktur utama (pimpianan), seluruh pengurus, dan karyawan dengan agenda dan jenis rapat yang berbeda, yaitu: rapat pimpinan, rapat pleno/rapat kerja, rapat divisi, rapat umum/rapat perguruan, dan rapat istimewa.

Setelah penulis melakukan penelitian dan pengamatan tentang manajemen strategik pondok Pesantren Al-Masthuriyah dalam upaya membentuk santri yang 
berkarakter, maka penulis ingin menyampaikan beberapa saran agar lebih baik: (1) Ditunjukan bagi Pondok Pesantren Al-Masthuriyah Sukabumi, Merumuskan strategi bukanlah hal yang mudah, perlu waktu, sumber daya yang cukup serta pemikiran yang mendalam mengenai analisis lingkungan dan stakeholders yang ada. oleh sebab itu, diharapkan keputusan-keputusan strategi yang telah dilaksanakan secara totalitas dan kesungguhan oleh semua elemen sumber daya pondok pesantren. Dengan perubahan lingkungan yang serba cepat, perkembangan teknologi serta pengetahuan dewasa ini yang mempengaruhi prilaku santri khususnya, Sedikit demi sedikit melunturkan budaya-budaya yang selama ini ada di Pondok Pesantren yang Bermanhaj Salafiyah, konsep karakter seorang santri (takrim, ta'dzim dan mahabbab) kepada guru pesantren sudah mulai berkurang. Padahal hal tersebut selain dari dari peroses ngaji, merupakan modal utama santri dalam mencapai ilmu yang bermanfaaat dunia dan akhirat. Sementara itu, untuk meningkatkan kualitas sumber daya manusia di Pondok Pesantren maka pemebrdayaan alumni adalah suatu alternatif strategis. Oleh karena itu, upaya penelusuran alumni dengan pemebantukan organisasi alumni harus dipertegas dan diperjelas dengan komitmen yang tinggi. Sehingga hal ini menjadi tanggung jawab bersama elemen pondok Pesantren Al-Masthuriyah. (2) Ditujukan bagi Jurusan Manajemen Dakwah, Perlu diketahuai bahwa Pondok Pesantren Al-Masthuriyah Sukabumi merupakan pondok pesantren yang besar dan mempunya perkembangan yang cukup pesat serta memeiliki ranah pengelolaan yag luas dan banyak. Oleh karena itu, masih banyak dimensi keilmuan lain yang menarik untuk diteliti secara komprehensif dan mendalam, terutama dari aspek kajian manajemen pondok pesantren. (3) Kepada peneliti yang lain, Hasil penelitian ini diharapkan dapat dijadikan rujukan sebagai bahan rujukan peneliti selanjutnya terkait tentang manajemen strategik pondok pesantren.

\section{DAFTAR PUSTAKA}

Bob, A. (2017). "Manajemen Komunikasi Entrepreneur Usaha Mikro Berbasis Pondok Pasantren." dalam Jurnal Ilmu Dakwah: Academic Journal for Homiletic Studies, 11.1 (2017): 133-150. 17 Dec. 2019

Dhofier, Z. (1983). Tradisi Pesantren : Studi Pandangan Hidup Kiai. Jakarta : LP3ES. Gozali, (2018). "Strategi Pondok Pesantren dalam Pengembangan Dakwah" dalam Jurnal Anida: Aktualisasi Nuansa Ilmu Dakwah , 17.1 (2017): 37-56. 17 Dec. 2019

Hasibuan, M.S.P. (2011). Manajemen : Dasar, Pengertian dan Masalah. Jakarta: Bumi Aksara.

Irsyad, (2008). Manajemen Strategi Organisasi. Jakarta: Kencana.

Ismail, (2012). Manajemen Strategik. Jakarta : Erlangga.

Kadmasasmita, A.D. (2005). Manajemen Strategis : Konsep Aplikasi. Bandung: 
Hasanudin, D. Kuswana, D. Sadiah.

Lembaga Admistrasi Negara RI Pusat Kajian dan Diklat Aparatur.

Kulsum, U. (2018). Manajemen Strategik dalam Pengelolaan Pesantren. dalam Jurnal Tadbir: Jurnal Manajemen Dakwah , 3.1: 84-99. 17 Dec. 2019

Madjid, M. \& Dian A. (2012). Pendidikan Karakter Perspektif Islam, Bandung: PT Remaja Rosdakarya.

Munir, dan Wahyu I. (2006). Manajemen Dakwah. Jakarta: Kencana.

Octavia, dkk. (2014). Pendidikan Karakter Berbasis Tradisi Pesantren. Jakarta : Rumah Kitab.

Qamar, M. (Tth). Pesantren Dari Transformasi Metodologi Menuju Demokerasi Institusi. Bandung: Erlangga.

Sadiah, D. (2015). Metode Penelitian Dakwah : Pendekatan Kualitatif dan Kuantitatif. Bandung : PT. Remaja Rosdakarya. 